DOI 10.2478/afpuc-2013-0009

ACTA FACULTATIS PHARMACEUTICAE UNIVERSITATIS COMENIANAE Supplementum VIII/2013

\author{
RARE DISEASES IN THE SLOVAK REPUBLIC \\ EUROPLAN NATIONAL CONFERENCE
}

\title{
PATIENT EMPOWERMENT IN RARE DISEASES \\ SLOVAK RARE DISEASE ALLIANCE - CONTRIBUTION \\ TO THE CREATION OF THE NATIONAL PLAN OF RARE DISEASES \\ IN SLOVAKIA \\ EURORDIS - BENEFITS OF MEMBERSHIP
}

Ramljaková $B$.

Slovak RD Alliance, DebRA SR

\begin{abstract}
After the endorsement of the National strategy of rare disease patient health care development for years 2012 - 2013 by the government of the SR on October 24, 2012, it is important for all participants in the process to get involved. (Who are all the participants? - doctors, pharmacists, scientist, national authorities, regulators, health insurance companies, social insurance company, health care and social workers, pharmaceutical industry, but also politicians, patients and patient organizations)

Based on the experience and problems which are being solved by patients, it is necessary for POs to focus on areas important for the creation of NP RD in the SR. These are most of all: complex approach to patients based on a multidisciplinary team, inclusion of patients into decision making - an educated patient is a prerequisite for this; specialized services for RD patients and their families; integration of RD patients into existing health care and social system and help lines.

Slovak Alliance of Rare Diseases (Alliance RD) was founded and registered at the Ministry of Interior of the SR on December 12, 2011. The reason for its foundation was the effort to solve problems in the area of RDs in a complex and systemic way, which is proved by its involvement in the creation of NP RD in the SR. It houses 12 POs working in the field of RD in Slovakia. The objective of the Alliance $\mathrm{RD}$ is to keep improving the health and social life conditions of rare disease patients and their families, to improve the quality of rare disease patients' lives, and to support their social integration.
\end{abstract}


In close cooperation with EURORDIS - Rare Disease Europe - it took part in EUROPLAN II (2012 - 2015), a project organized by the National conference for the support of the creation of National plan of rare disease patient health care development in Slovakia.

Keywords: Alliance RD-National strategy - National plan-EURORDIS

National strategy of RDs in the Slovak Republic for years 2012 - 2013 was approved on the $24^{\text {th }}$ October 2012 by Slovak government. It is crucial for all stakeholders to be involved in this process in order to ensure good results. Who are all the stakeholders? Physicians, academics, researchers, pharmacists, pharma industry, national authorities, regulators, medical insurance companies, social insurance, medical and social workers, politicians, patients, and patient organizations as well.

People affected by rare diseases face common challenges such as:

- Diagnostic delay

- Misdiagnosis

- Lack of information

- Lack of access to experts and standards of care

- Lack of choice of treatment

- Psychological stress

- Lack of practical support for everyday life

Patient organizations need to be active and work on the following points in the process of creating the National plan of RDs in Slovakia:

1. There is a strong need to adopt holistic approach to individual citizens. For people living with rare diseases, care should not only be restricted to medical and paramedical aspects, but it should also take into account social inclusion and psychological aspects. Patient organizations should closely cooperate with physicians, psychologists, and social workers.

2. Patients and their leaders should be involved in the decision making process in the field of rare diseases. This would be possible only if the patient is an equivalent partner for national authorities. Educated patient.

3. Specialised social services are an important instrument for the empowerment of people living with rare diseases and the improvement of their health and lives; Respite Care Services (RCS), Therapeutic Recreation Programmes (TRP), Adapted Housing (AH), and Resource Centres (RC) in particular. RCS is provided on a short term basis for disabled or very ill people who either live at home or attend respite centres. Their caregivers can have a break from care giving. TRPs for rare disease patients are organized recreation activities which give children possibility to have fun and take a break from thinking about the disease. AHs allow people living with rare diseases to develop and enjoy some autonomy in their own homes under supervision of staff. It is better than being placed in an institution. RCs are a new type of service. It is a combination of information and social and medical services. 
4. People living with rare diseases (PLWRD) need to be recognized and integrated into the existing social system and quality services responding to their needs must be provided. It is important to consider also other factors apart from the functional character of disorder, such as its chronic character and degenerative processes.

5. Help lines - the primary role of help lines is to provide information and support to callers.

Other activities of Patient organizations (PO) in the process of creating NP RD SR are networking and cooperation between POs, raising awareness about RDs, international cooperation (EURORDIS), spreading information through websites, educational activities, collaboration with media, releasing promotional materials.

\section{Slovak RD Alliance}

Slovak RD Alliance was founded in December 2011 to promote the well-being of people living with rare diseases in Slovakia.

Alliance's mission is to improve quality of health care and social services of patients living with rare diseases and their families and to fight against the impact of rare disease on their lives. It is a network of 12 patient associations in the Slovak Republic that supports people affected by particular rare diseases.

The main goal is to participate in the creation and adoption of National Plan of RDs in Slovakia and to connect PO with RD.

Some of our achievements:

- EURORDIS membership

- Active participation at 6. European congress of rare diseases in Brussels

- Mediation of health care

- Contribution to the work in the working group of experts (WG) created by Ministry of Health SR

- Contribution to the Interdepartmental WG

- Interdepartmental comments of National strategy proposal

- $\quad$ Publishing newsletter MINORIT

- Launching websites http://www.sazch.sk/, http://www.zriedkave-choroby.sk/

- $\quad$ Organization of the Rare Disease Day in Slovakia

- Counselling and information for people living with RDs and their families

EURORDIS is a non-governmental patient-driven alliance of patient organisations representing 561 rare disease patient organisations in 51 countries covering over 4000 diseases at this moment.

EURORDIS mission is to build a strong pan-European community of patient organisations and people living with rare diseases; and to be their voice at the European level and fight against the impact of rare diseases on their lives.

Why to become a member of EURORDIS?

- Be represented at key European Institutions, such as the European Commission, the European Medicines Agency (EMA)

- Post your news and announcements in the "Members News and Announcements" section of the EURORDIS website 
- Participate in training sessions, such as the EURORDIS Summer School for Patient Advocates in Drug Development, Clinical Trials \& Regulatory Affairs

- Obtain fellowships to attend conferences such as the European Conference on Rare Diseases, \& Orphan Products, the Drug Development Association's EuroMeeting and others

- $\quad$ Participate in the EURORDIS Membership Meeting, conference and capacity building workshops

Slovak RD Alliance has collaborated with EURORDIS from the first moment of establishing the Alliance in Slovakia. One of its main points is to make rare diseases a public health priority in Slovakia.

\section{REFERENCES}

EURORDIS. The voice of 12,000 patients: Experiences and Expectations of Rare Disease Patients on Diagnosis and Care in Europe : a report based on the EurordisCare3 surveys [online]. Eurordis, 2009 ISBN 29-530-3181-2.

(www.eurordis.org/IMG/pdf/voice_12000_patients/EURORDISCARE_FULLBOOKr.p df). Accessed April 202013.

EURORDIS. EUROPLAN - Guidance for National Plans and Conferences: EUROPLAN National Conference Final Reports [online]. EURORDIS, 2010, 21/09/2012. (http://www.eurordis.org/content/europlan-guidance-national-plans-andconferences). Accessed April 202013.

EURORDIS. EURORDIS Rare Diseases Europe: The voice of of Rare Disease Patients in Europe [online]. European Union's Health Programme, 2009, 10/01/2013.

(http://www.eurordis.org/). Accessed April 202013.

Ing. Beáta Ramljaková

Karpatská 28

Stupava

90031

Slovakia

ramljakova@gmail.com 


\section{PACIENTSKE ORGANIZÁCIE V OBLASTI ZRIEDKAVÝCH CHORÔB - ICH ČINNOSŤ AJ PRI PRÍPRAVE NÁRODNÉHO PLÁNU V SR SLOVENSKÁ ALIANCIA ZRIEDKAVÝCH CHORÔB EURORDIS -EURÓPSKA ALIANCIA ZRIEDKAVÝCH CHORÔB - VÝHODY ČLENSTVA}

\section{Ramljaková B.}

Slovenská aliancia zriedkavých chorôb (Aliancia ZCH), DebRA SR

Po schválení Národnej stratégie rozvoja zdravotnej starostlivosti o pacientov so zriedkavými chorobami na roky 2012 - 2013 dňa 24.10.2012 vládou SR je dôležité pre všetkých účastníkov procesu, aby sa zapojili. (Kto sú všetci účastníci? - lekári, farmaceuti, vedci, národné autority, regulátori, zdravotné poist'ovne, sociálna poist'ovn̆a, zdravotní a sociálni pracovníci, farmaceutický priemysel, ale aj politici, pacienti a pacientske organizácie)

$\mathrm{Na}$ základe svojich skúseností a problémov, ktoré pacienti riešia je potrebné, aby sa PO zamerali na okruhy dôležité pri vypracovaní NP ZCH v SR, a to predovšetkým na komplexný prístup $\mathrm{k}$ pacientovi na základe multidisciplinárneho tímu, na začlenenie pacientov do rozhodovacích procesov - predpokladom je tu vzdelaný pacient, na špecializované služby pre pacientov so $\mathrm{ZCH}$ a ich rodiny, na integrovanie pacientov so ZCH už do existujúceho zdravotného a sociálneho systému a linky pomoci pre pacientov (Help lines).

Slovenská aliancia zriedkavých chorôb (Aliancia ZCH) vznikla 12.12.2011 registráciou na MV SR a dôvodom prečo vznikla, je snaha riešit' problémy $\mathrm{v}$ oblasti $\mathrm{ZCH}$ komplexne a systémovo, čoho dôkazom je zapojenie sa do tvorby NP ZCH v SR. Združuje zatial' 12 PO v oblasti ZCH na Slovensku. Poslaním Aliancie ZCH je trvale zlepšovat' zdravotné a sociálne podmienky života l'udí so $\mathrm{ZCH}$ a ich rodinných príslušníkov. Zvyšovat' kvalitu života l'udí so $\mathrm{ZCH}$ a podporovat' ich integráciu do spoločnosti.

V úzkom partnerstve s EURORDIS - Európskou alianciou zriedkavých chorôb sa zapojila do projektu EUROPLAN II (2012 - 2015) organizovaním Národnej konferencie na podporu vypracovania Národného plánu rozvoja starostlivosti o pacientov so ZCH na Slovensku.

Acta Fac. Pharm. Univ. Comen. 2013, Suppl VIII:41-45. 